\title{
Оцінка постурального балансу юніорів, що спеціалізуються в гандболі
}

\author{
УДК 612.76+612.84+616-072.7 \\ О. В. Колосова, Б. Ю. Коломієць, \\ Е. І. Петрушевський
}

Національний університет фізичного виховання і спорту України, Київ, Україна

Резюме. Мета. Дослідити постуральний баланс у групі кваліфікованих юніорів, які спеціалізуються у гандболі, і виявити його можливі функціональні порушення за допомогою методу стабілометрії. Методи. Метод стабілометрії з використанням стабілометричної платформи Nintendo Wii Board (Японія-Китай).

Результати. У 29 \% осіб із групи кваліфікованих юніорів (чоловіків 16-17 років), які спеціалізуються у гандболі, спостерігалися відхилення від референтних значень деяких стабілометричних показників основної вертикальної стійки, а саме - середнє положення центру тиску стоп (ЦТС) у фронтальній площині було зміщено більше ніж на 10 мм вправо або вліво від центральної поздовжньої осі платформи. У 41 \% спортсменів ЦТС у фронтальній площині також істотно переміщувався при звуженні бази опори на платформу. Таке зміщення центру статокінезіограми може бути ознакою прихованих порушень постурального балансу та міжм'язової координації, що може збільшити ризик травматизму. Висновки. У групі кваліфікованих юніорів (чоловіків), що спеціалізуються у гандболі, у третини осіб виявлено відхилення стабілометричних параметрів від норми, яке свідчить про значну асиметрію основної вертикальної стійки, що збільшує ризик травматизму. Існує необхідність регулярної оцінки постурального балансу спортсменів, а також розробки та широкого використання комплексу вправ, спрямованих на розвиток стійкості, з використанням методу біологічного зворотного зв'язку, з метою профілактики травмування.

Ключові слова: постуральний баланс, стабілометрія, центр тиску стоп, спортсмени-гандболісти.

\section{Evaluating postural balance of juniors specialized in handball}

O. V. Kolosova, B. I. Kolomiiets, E. I. Petrushevskyi

National University of Physical Education and Sport of Ukraine, Kyiv, Ukraine

Abstract. Objective. The purpose of our work was to investigate the postural stability in the group of male junior athletes specialized in handball in order to find possible functional disorders by means of stabilometry method.

Methods. Stabilometry study using force platform Nintendo Wii Board (Japan-China).

Results. It was found that $29 \%$ of skilled junior handballers (males aged 16-17 years) had deviations in some stabilometric indices of the main vertical stance from the established standard values. The abnormalities were characterized by left or right displacement of the center of pressure (COP) position in the frontal plane by more than $10 \mathrm{~mm} .41 \%$ of athletes showed also COP displacement in conditions of posture with small footing base. These changes could serve as diagnostic sign of disorders of postural balance and muscle coordination that might increase risk of sports injuries.

Conclusion. It was found that one third of male junior handball players had deviations in the stabilometric parameters that might be due to the substantial asymmetry of the upright stance that could increase injury risk. It is necessary to regularly assess athletes' postural balance and to develop and widely use the complex of exercises aimed at stability development with the use of the biofeedback postural stability method for injury prevention.

Keywords: postural balance, stabilometry, center of pressure, handball players. 
Постановка проблеми. У сучасному світі спортивних ігор гандбол займає одне 3 провідних місць. Гандболіст-професіонал повинен бути добре розвинений фрізично, мати високий рівень швидкісних, силових здібностей, координації рухів і витривалості [8]. Однак сучасна підготовка спортсменів високого класу потребує напружених режимів тренування та висуває високі вимоги до організму спортсмена, зокрема до опорно-рухового апарату, що призводить до підвищення рівня травматизму [3, 5].

Однією з причин перенапруження опорно-рухового апарату вважають м'язовий дисбаланс, викликаний порушенням координації м'язівантагоністів у результаті довготривалого виконання однотипних тренувальних вправ та впливу травмуючих навантажень. Це призводить до зниження фріксуючої функції багатосуглобових м'язів з подальшим послабленням сумочно-зв'язкового апарату, якому доводиться витримувати невластиві йому навантаження під час виконання спортивних рухів [3, 5, 11].

М'язово-скелетні травми $\epsilon$ одними із найсерйозніших проблем спортивної медицини, вирішення яких потребує великих економічних витрат. Вони призводять до пропусків тренувань та змагань, а також до зниження спортивних результатів [18]. За даними літератури, гравці командних видів спорту з м'ячем, таких, як гандбол, футбол та баскетбол, особливо схильні до отримання м'язово-скелетних травм (гострих та пов'язаних із перевантаженням) [13, 14]; при цьому, за даними медичних обстежень, переважна більшість травм, отриманих спортсменами-гандболістами, були пов'язані з травмуванням м'язів та суглобів [15].

На думку деяких дослідників, на сьогодні не існує широко впровадженої специфрічної превентивної тренувальної програми для попередження травмування верхніх та нижніх кінцівок [12]. В той же час доведено ефективність комплексних довготривалих програм, спрямованих на пропріоцептивне та силове тренування, у зниженні кількості спортивних травм більше ніж удвічі [17].

Для контролю за ефективністю реабілітаційних та тренувальних процесів з дослідженням механізмів постурального контролю можна успішно використовувати стабілометричний метод $[1,10$, 19, 24]. У постуральній регуляції задіяні різні функціональні системи організму: опорно-рухова, центральна та периферійна нервова системи. Серед органів чуття необхідно особливо відмітити пропріоцептивну та зорову системи, котрі несуть основне навантаження; має значення також і вестибулярний апарат [7]. Центральна нервова система здійснює інтеграцію всіх сенсорних сигналів, що надходять з різних рецепторів тіла, та формує рухові імпульси для постуральних м'язів з метою забезпечення стійкості положення тіла [6]. Характеристики коливань (амплітуда, частота, напрямок) є чутливими параметрами, що відображають стан різних систем, які беруть участь у підтриманні балансу тіла [7].

Відмінності постурального балансу спортсменів та фізично активних осіб виявляються особливо у специфрічних умовах: наприклад, при стоянні $з$ вузькою площею опори або після виконання спортивних вправ - стрибків, обертань тощо [24]. За даними літератури, вид спорту й рівень активності спортсмена впливають на різні підсистеми контролю пози [21]. Так, у спортсменок-акробаток спостерігається більш стабільний та менш залежний від зорового аналізатора баланс тіла в основній вертикальній стійці, ніж у танцівниць балету [16]; у спортсменів ігрових видів спорту (баскетбол, волейбол) та представників стендової стрільби постуральна стійкість краще, ніж у контрольній групі [9].

Стабілометричне дослідження дозволяє оцінити не тільки постуральний баланс тіла спортсмена в стані спокою, але i його зміни під впливом різних фракторів, таких, як стомлення, викликане фрізичним навантаженням [23], або травмування передньої хрестоподібної зв'язки коліна [20]. Недостатньо вивченими залишаються особливості постурального балансу спортсменів, які спеціалізуються у різних видах спорту, з урахуванням їх амплуа, статі, а також впливу різних програм тренування та реабілітації.

Роботу виконано у відповідності з госбюджетною науково-дослідницькою темою «Технологія оцінки ризику травматизму спортсменів за електронейроміографрічними і психофрізіологічними показниками» (номер держрегістрації $0119 U 000307$ Міністерства освіти та науки України).

Мета дослідження - вивчити постуральний баланс у групі кваліфрікованих юніорів, які спеціалізуються у гандболі, і виявити його можливі функціональні порушення за допомогою методу стабілометрії.

Для досягнення поставленої мети необхідно було оцінити стан постурального балансу спортсменів; розрахувати амплітудно-швидкісні показники переміщення центру тиску стоп (ЦТС) та проаналізувати зміни цих показників у різних положеннях тіла спортсмена; оцінити внесок зору та пропріоцептивного відчуття у підтримання вертикальної стійки; виявити можливі функціональні порушення постурального балансу з використанням методу стабілометрії. 
Методи і організація дослідження. У дослідженні брали участь 17 кваліфікованих юніорів (чоловіків), які спеціалізуються у гандболі (КMC), у віці 16-17 років, без неврологічних захворювань в анамнезі і ознак неврологічної патології на момент обстеження. У 12 осіб домінуючою верхньою кінцівкою була права, а у 5 ліва.

Було отримано антропометричні показники: довжина тіла (м), маса тіла (кг) та індекс маси тіла (IMT, кг $\left.\cdot \mathrm{M}^{-2}\right)$. Стабілометричне дослідження проводили за допомогою стабілометричної платорорми Nintendo Wii Board (Японія-Китай). Дослідження проводили в умовах прямої вертикальної стійки, яку в стабілометрії зазвичай позначають терміном «основна стійка». Під час тесту спортсмен стояв на стабілоплаторормі без взуття, руки вздовж тулуба. Проводили чотири проби: основна вертикальна стійка із широкою базою опори (відстанню між стопами), а саме зручним положенням стоп на ширині плечей, 3 відкритими та закритими очима; вертикальна стійка зі звуженою базою опори, а саме - стопи разом, з розплющеними та заплющеними очима. Час реєстрації кожної проби дорівнював 20 с.

Для кожної проби визначали такі стабілометричні показники: Хс, мм - середнє положення ЦТС по осі абсцис (у фронтальній площині; негативне значення $\mathrm{X}$ відповідало його зміщенню вліво від центра координат платфрорми, а позитивне - вправо), Үс, мм - середнє положення ЦТС по осі ординат (у сагітальній площині; негативне значення $\mathrm{Y}$ відповідало його зміщенню назад від центра координат, а позитивне - вперед); XSD, мм - розкид (середнє квадратичне відхилення) у фронтальній площині, YSD, мм розкид (середнє квадратичне відхилення) у сагітальній площині; VX, мM $\cdot \mathrm{c}^{-1}$ - середня швидкість переміщення ЦТС у фронтальній площині, VY, мм $\cdot \mathrm{c}^{-1}$ - середня швидкість переміщення ЦТС у сагітальній площині, V, мм $\cdot \mathrm{c}^{-1}-$ середня швидкість переміщення ЦТС у двомірній системі координат. Розраховували також VY /VX - відношення VY до VX. Статистичний аналіз даних проводили за допомогою програми SPSS 17.0. Для оцінки залежності певної величини від зорової депривації та звуження бази опори на платсрорму проводили 2-фракторний дисперсійний аналіз. При цьому міжгруповими фракторами виступали наявність зорового контролю, яка мала дві категорії - розплющені та заплющені очі, і ширина вертикальної стійки, що складалася 3 двох рівнів - широка і вузька база опори на платформу. За рівень статистичної значущості приймали $p<0,05$. Статистичну значущість різ-
ТАБЛИЦЯ 1 - Антропометричні показники спортсменівчоловіків, які спеціалізуються у гандболі (mean \pm se)

\begin{tabular}{|c|c|c|c|}
\hline Вік, роки & Довжина тіла, м & Маса, кг & $\begin{array}{c}\text { Масо-зростовий } \\
\text { індекс, кг·м }\end{array}$ \\
\hline $\begin{array}{c}16,8 \pm 0,4 \\
(16-17)\end{array}$ & $\begin{array}{c}1,847 \pm 0,054 \\
(1,72-1,93)\end{array}$ & $\begin{array}{c}77,9 \pm 6,1 \\
(66,1-93,8)\end{array}$ & $\begin{array}{c}22,8 \pm 1,4 \\
(20,4-24,8)\end{array}$ \\
\hline
\end{tabular}

ниці середніх значень груп параметрів визначали за допомогою порівняльного аналізу ANOVA.

Під час проведення комплексних біологічних обстежень за участю спортсменів дотримувалися розробленої в НДІ НУФВСУ «Програми комплексного біологічного дослідження особливостей функціональних можливостей спортсменів», а також законодавства України про охорону здоров'я та Гельсінської декларації 2000 р., директиви Європейської Спілки 86/609 відносно участі людей у медико-біологічних дослідженнях.

Результати дослідження та їх обговорення. Антропометричні показники юніорів (середні по групі, мінімальні та максимальні значення) представлені в таблиці 1.

Аналіз результатів наших досліджень показав, що у більшості спортсменів із групи стабілометричні показники в основній вертикальній стійці 3 широкою базою опори з відкритими очима знаходилися в межах норми, але у $29 \%$ осіб спостерігалися відхилення деяких параметрів від референтних значень, а саме - ЦТС у фронтальній площині був зміщений більше ніж на 10 мм праворуч або ліворуч від центральної поздовжньої осі платформи (рис. 1, А). Це узгоджується з даними інших дослідників, за якими у $25 \%$ спортсменів, котрі спеціалізуються в ігрових видах спорту, $\epsilon$ аналогічна асиметрія пози [4]. Можна було 6 припустити, що такі зміщення положення ЦТС викликані переважною опорою на домінуючу нижню кінцівку, але не було виявлено статистично значущого кореляційного зв'язку між домінуванням нижньої кінцівки та латеральною асиметрією показників. За літературними даними, зміщення центра кривої статокінезіограми вправо або вліво відносно центра координат стабілоплаторорми на 10 мм та більше може свідчити про приховані постуральні порушення [2, 7]. Така тенденція відмічається також у $27 \%$ спортсменів силових видів спорту, 12,5\% - легкоатлетів, $25 \%$ - велосипедистів [4].

За результатами дисперсійного аналізу впливу зорової депривації та ширини стійки на стабілометричні показники спортсменів, фрактор зорового контролю мав статистично значущий вплив на розкид у фронтальній та у сагітальній площинах, а також на всі показники швидкості 

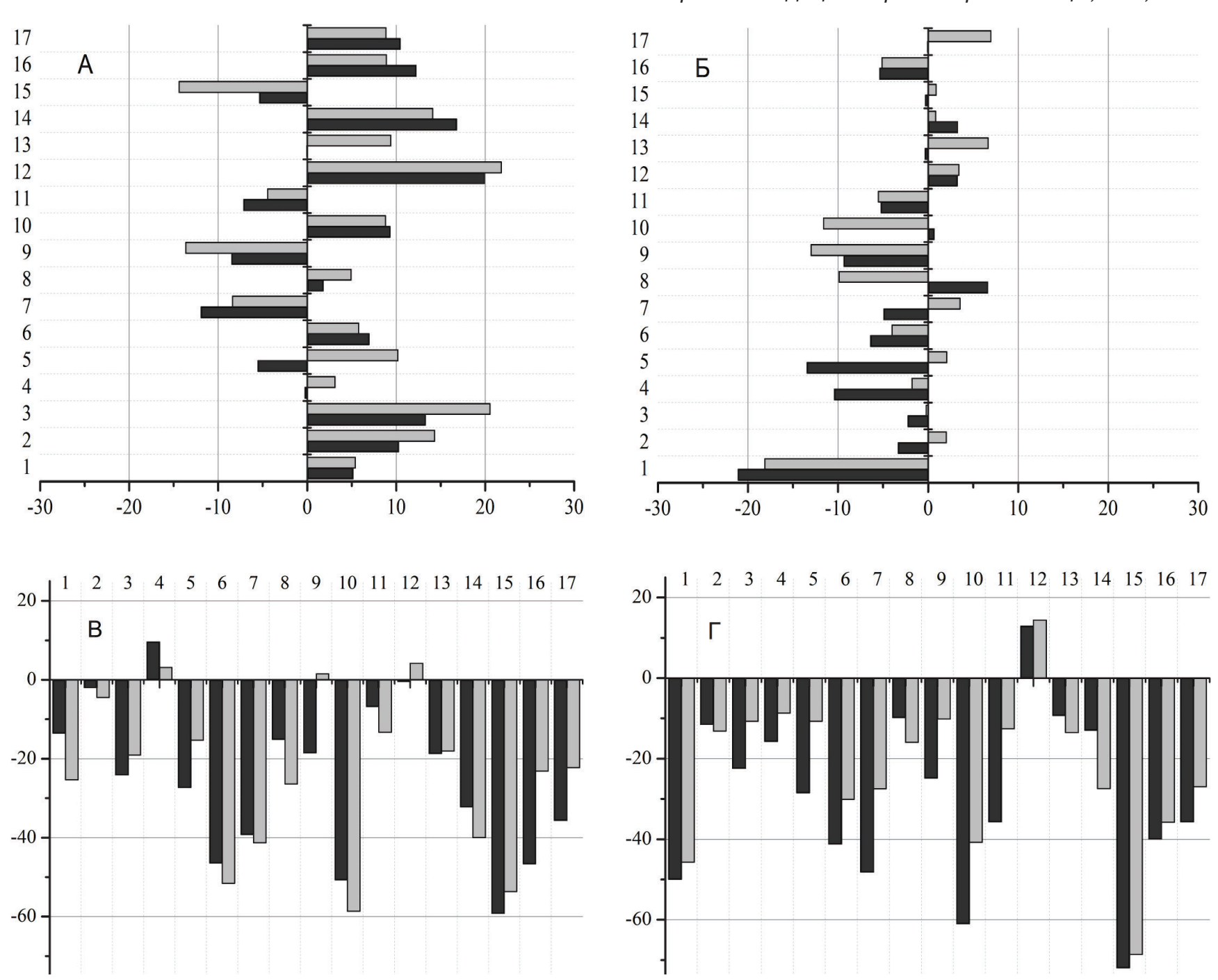

Рисунок 1 - Положення центру тиску стоп на стабілометричній платорормі:

А, Б - у фронтальній площині (А - з широкою базою опори, Б - з вузькою базою опори) В, Г - у сагітальній площині (В - з широкою базою опори, Г - з вузькою базою опори). Темно-сірі стовпчики - розплющені очі, світлосірі стовпчики - заплющені очі. 1-17: порядкові номери спортсменів. Відстані на осях ординат надано у міліметрах

переміщення ЦТС, тобто при заплющених очах площа статокінезіограми та швидкість ЦТС більше, ніж при розплющених очах (табл. 2, рис. 3). Це узгоджується із результатами, отриманими при дослідженнях постурального балансу воротарів-юніорів національної гандбольної команди Польщі: швидкість ЦТС була більшою в тестах, що проводилися із заплющеними очима [22].

Фактор ширини стійки, що пов'язаний із зручністю пози, мав статистично значущий вплив на розкид у фронтальній та у сагітальній площинах, на всі показники швидкості переміщення ЦТС (рис. 3), а також на положення ЦТС у фрронтальній площині. Таким чином, площа статокінезіограми та швидкість ЦТС була більше у звуженій стійці, крім цього, при зменшенні бази опори в цілому по групі спостерігалося і статис- тично значуще переміщення ЦТС, незважаючи на велику індивідуальну варіативність цього показника (табл. 2).

Потрібно підкреслити, що середнє положення ЦТС у сагітальній площині не залежало від зорового контролю та ширини стійки, тоді як середнє положення ЦТС у фронтальній площині зазнавало незначних змін при зоровій депривації (у переважної більшості осіб), але істотно змінювалося при звуженні бази опори. При цьому у більшості спортсменів спостерігалося зміщення в лівий бік, і у $41 \%$ осіб із групи величина зміщення значно перебільшувала 10 мм (рис. 2, Б). При цьому не було виявлено значущого кореляційного зв'язку між домінуванням нижньої кінцівки та асиметрією показників. Отже, таке істотне переміщення ЦТС може бути ознакою прихованих по- 
ТАБЛИЦЯ 2 - Результати дисперсійного аналізу впливу зорового контролю та ширини стійки на стабілометричні показники спортсменів, які спеціалізуються у гандболі (mean $\pm \mathrm{se})$

\begin{tabular}{|c|c|c|c|c|c|c|}
\hline \multirow[t]{2}{*}{ Параметр } & \multicolumn{2}{|c|}{$\begin{array}{l}\text { Зоровий } \\
\text { контроль }\end{array}$} & \multicolumn{2}{|c|}{ Ширина стійки } & \multicolumn{2}{|c|}{$\begin{array}{c}\text { Зоровий } \\
\text { контроль } \times \\
\text { ширина стійки }\end{array}$} \\
\hline & $\mathbf{F}$ & $\mathrm{p}$ & $\mathbf{F}$ & $\mathbf{p}$ & $\mathbf{F}$ & p \\
\hline Xc, mM & 0,565 & 0,455 & 14,776 & $0,000^{\star *}$ & 0,001 & 0,977 \\
\hline Yc, mM & 0,778 & 0,381 & 0,131 & 0,719 & 0,362 & 0,550 \\
\hline XSD, мM & 9,027 & $0,004^{\star *}$ & 140,149 & $0,000^{* *}$ & 7,571 & $0,008^{\star \star}$ \\
\hline YSD, мм & 4,520 & $0,037^{*}$ & 10,665 & $0,002^{\star *}$ & 0,005 & 0,946 \\
\hline$V X, \mathrm{MM}^{\prime} \mathrm{c}^{-1}$ & 14,693 & $0,000^{\star *}$ & 175,411 & $0,000^{\star *}$ & 9,630 & $0,003^{\text {** }}$ \\
\hline $\mathrm{VY}, \mathrm{MM} \cdot \mathrm{c}^{-1}$ & 28,932 & $0,000^{\star *}$ & 22,271 & $0,000^{* *}$ & 1,066 & 0,306 \\
\hline $\mathrm{V}, \mathrm{MM} \cdot \mathrm{c}^{-1}$ & 30,948 & $0,000^{* *}$ & 88,496 & $0,000^{* *}$ & 4,674 & $0,034^{*}$ \\
\hline VYIX & 13,558 & $0,000^{* *}$ & 63,279 & $0,000^{* *}$ & 5,681 & $0,020^{*}$ \\
\hline
\end{tabular}

${ }^{*} p<0,05,{ }^{* *} p<0,01$.
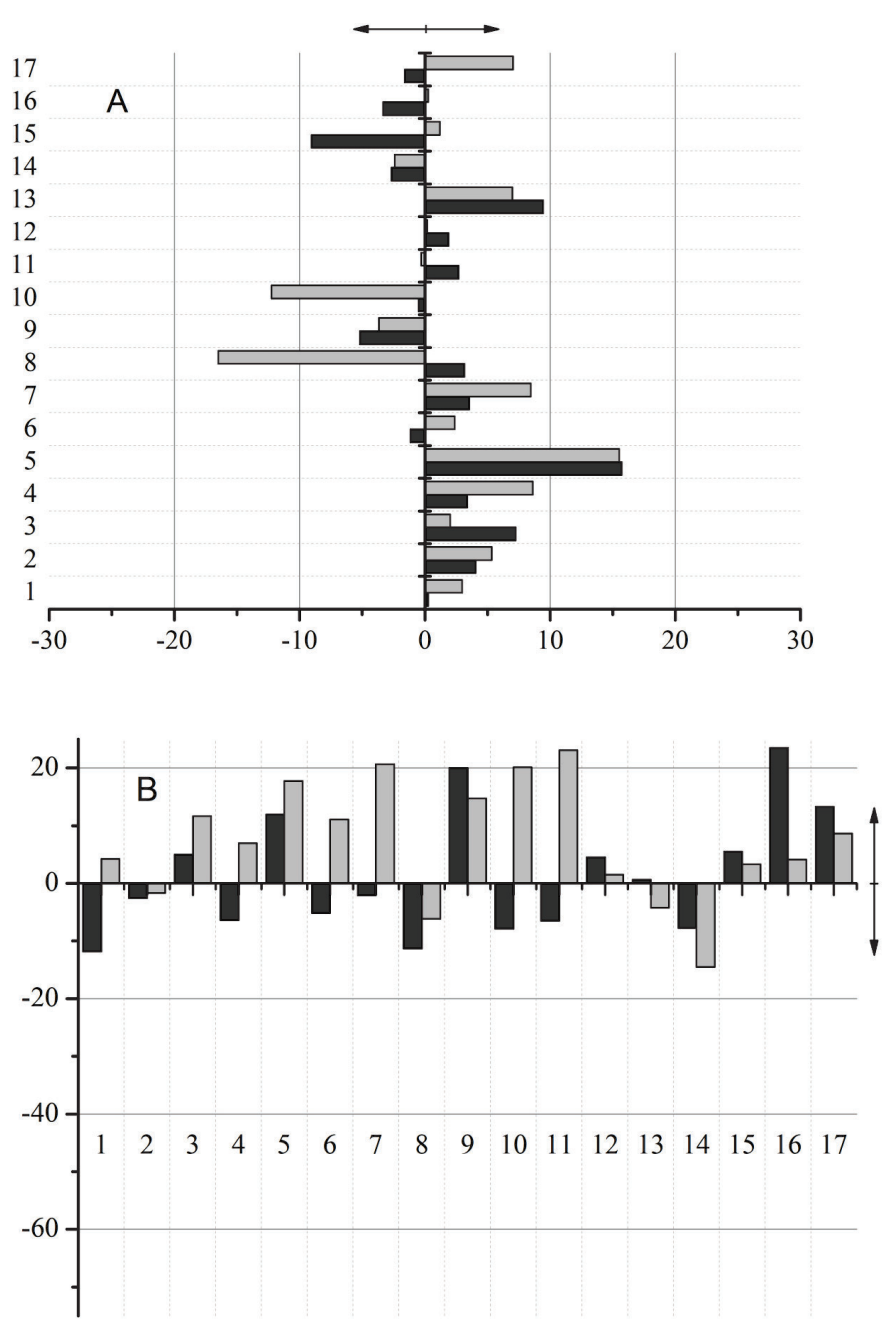

рушень міжм'язової координації та пропріоцептивного відчуття.

Взаємодія фракторів зорового контролю та ширини стійки мала статистично значущий вплив на розкид у фронтальній площині, на показники швидкості переміщення ЦТС у фронтальній площині та загальний показник швидкості і співвідношення швидкості переміщення ЦТС у сагітальній площині до фрронтальної. Водночас не відмічалося значущого впливу взаємодії фракторів на параметри, що безпосередньо пов'язані із Ү-коливаннями.

Окремо необхідно підкреслити важливість показника VY/X, який відображає переважну участь коливань у сагітальній або фронтальній площинах у підтриманні вертикальної стійки. В

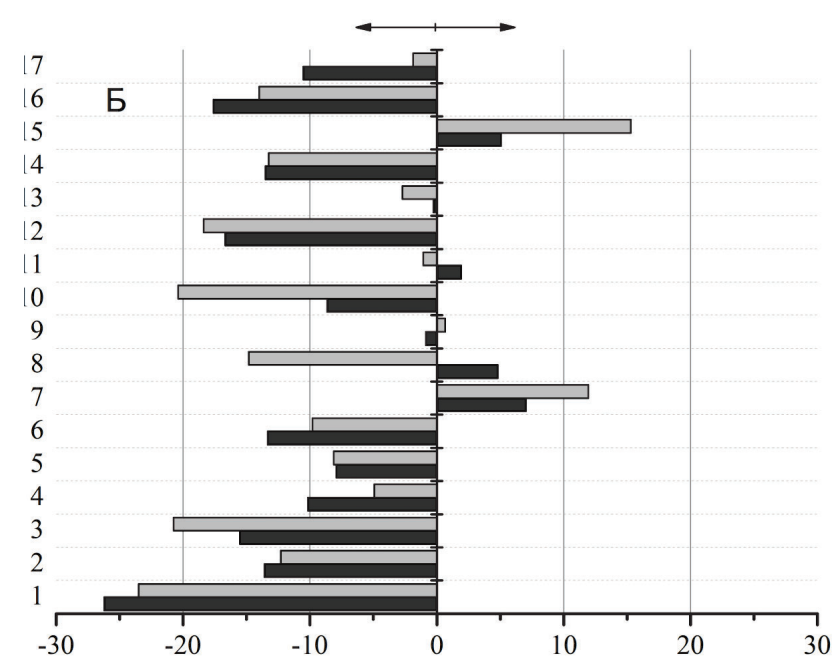

Рисунок 2 - Зміни положення центру тиску стоп на стабілометричній платформі при зміні умов вертикальної стійки:

А, Б - у фронтальній площині (А - вплив зорової депривації, Б - вплив звуження площини опори); В, Г - у сагітальній площині (В - вплив зорової депривації, Г - вплив звуження площі опори). А, В: темно-сірі стовпчики - широка площа опори, світло-сірі стовпчики - вузька площа опори. Б, Г: темно-сірі стовпчики - розплющені очі, світло-сірі стовпчики - заплющені очі. 1-17: порядкові номери спортсменів. Відстані на осях ординат надано у міліметрах 

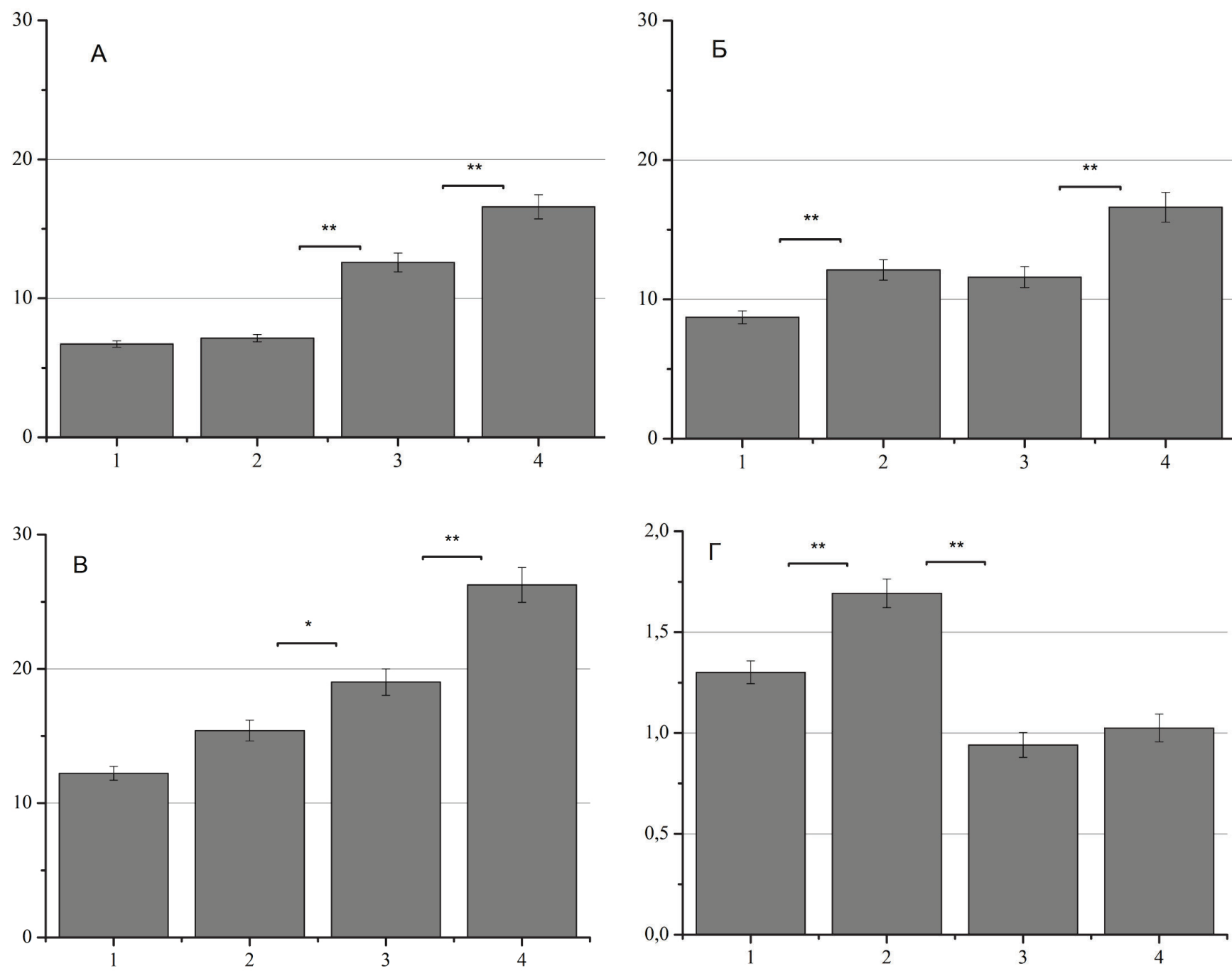

Рисунок 3 - Показники швидкості переміщення центру тиску стоп на стабілометричну платфрорму при зміні умов вертикальної стійки:

А - швидкість переміщення ЦТС у фронтальній площині; Б - швидкість переміщення ЦТС у сагітальній площині; В - загальна швидкість переміщення ЦТС (у двомірній координатній системі); Г - співвідношення значень швидкості переміщення ЦТС у сагітальній площині до значення у фронтальній. 1 - широка площа опори, очі розплющені; 2 - широка площа опори, очі заплющені; 3 - вузька площа опори, очі розплющені; 4 - вузька площа опори, очі заплющені. *p <0,05; ** $p<0,01$

основній стійці з широкою базою опори, з розплющеними очима цей показник зазвичай вище одиниці, тобто тіло людини коливається більше у напрямку вперед-назад, ніж вліво-вправо [7]; це підтверджується і нашими даними, $V Y / X=1,30 \pm 0,05$ (рис. 3, Г). При заплющенні очей переважання Ү-коливань ще збільшується, $\mathrm{VY} / \mathrm{X}=1,69 \pm 0,07$. Але в умовах стійки зі звуженою базою опори спостерігається переважання коливань у фронтальній площині над сагітальними, $\mathrm{VY} / \mathrm{X}=0,94 \pm 0,06$, при закриванні очей частка Y-коливань збільшується (VY $/ \mathrm{X}=$ $=1,02 \pm 0,07)$, але залишається меншою порівнянно із широкою стійкою (рис. 3, Г).
Отже, ускладнення умов вертикальної стійки, такі, як зорова депривація та звуження бази опори тіла, призводять до змін амплітудношвидкісних параметрів коливань у фронтальній і сагітальній площинах, при цьому звуження бази опори тіла та взаємодія фракторів зорового контролю та ширини стійки здійснює більший вплив на медіо-латеральні коливання тіла спортсмена (рис. 3).

Таким чином, дані, отримані за допомогою стабілометричного методу дослідження, дозволяють оцінити стан постурального балансу спортсменів, виявити його порушення внаслідок дезадаптації до фрізичного навантаження, спрог- 
нозувати ризик травматизму, встановити особливості фуннкціонування нервово-м'язового апарату спортсменів, пов'язані з переважним використанням певної сенсомоторної системи для підтримання вертикальної стійки. Показники асиметрії центру тиску стоп у фронтальній площині та переміщення центру тиску стоп при зміні пози тіла можна використовувати як діагностичні критерії фрункціонування нервово-м'язової системи, що дозволяють вчасно виявити передпатологічний стан. На думку сучасних дослідників, тестування постуральної стійкості $\epsilon$ важливим елементом координаційного тренування із застосуванням методу біологічного зворотного зв'язку на стабілометричних платорормах, яке необхідно впроваджувати у повсякденну спортивну практику для попередження травмування гандболістів-юніорів $[12,22]$. Отримані результати стануть у нагоді тренерам та спортивним лікарям для розробки індивідуальної тренувальної та реабілітаційної програми, спрямованої на профілактику травматизму та збереження здоров'я спортсмена.

\section{Висновки}

1. Встановлено, що у $29 \%$ кваліфікованих чоловіків-юніорів, які спеціалізуються у гандболі, $\epsilon$ відхилення стабілометричних параметрів від референтних значень, а саме - зміщення положення центру тиску стоп від центру координат більше, ніж на 10 мм у фрронтальній площині в основній вертикальній стійці зі зручним положенням стоп, а

\section{Література}

1. Болобан ВН, Мистулова ТЕ. Стабилография: достижения и перспективы [Stabilography: achievements and prospects]. Наука в олимпийском спорте. Спещиальный выпуск ГНИИФК. 2000: 5-13.

2. Быков ЕВ. Динамика показателей стабилометрии в соревновательном периоде в оценке функционального состояния хоккеистов [Dynamic of stabilometric indices in competitive period in assessing of hokkey athletes functional state]. Фундаментальные исследования. 2012; 9, 4: 796-800.

3. Денисенко ЮП. Релаксационные характеристики скелетных мышц в повышении физической работоспособности футболистов [Relaxation indices of skeletal muscles for increasing physical performance in footballers]. Вестник спортивной науки. 2007; 1: 27-31.

4. Замчий ТП, Ложкина-Гамецкая НИ, Спатаева МХ. Асимметрия в поддержании вертикальной позы у спортсменов разных специализаций [Upright stance asymmetry in athletes performing different sports]. Современные проблемы науки и образования. 2014; 3: 1-9.

5. Колесниченко ВА, Продан АИ, Тяжелов АА. Механогенез синдромов перенапряжения у спортсменов [Mechanical origin of physical exertion syndrome in athletes] Травматология и ортопедия России. 2007; 1: 37-44.

6. Левик ЮС. Стабилография в исследованиях управления позой [Stabilography in the investigation of posture regulation]. Известия ЮФУ. Технические науки. 2008; 6: 108-12.

7. Скворцов ДВ. Стабилометрическое исследование: краткое руководство [Stabilometric study: short guidance]. Москва: Мера-ТСП; 2010. 172 c. також у $41 \%$ спортсменів із обстежуваної групи спостерігається значне переміщення ЦТС в умовах звуження бази опори на платформу. Це може бути ознакою порушення постурального балансу та міжм'язової координації внаслідок реакції нервово-м'язової системи на дію неадекватного навантаження та збільшує ризик травматизму.

2. Ускладнення умов вертикальної стійки, такі, як зорова депривація та звуження бази опори тіла, призводять до змін амплітудно-швидкісних параметрів коливань у фронтальній і сагітальній площинах, при цьому зміна бази опори тіла та взаємодія фракторів зорового контролю та ширини стійки здійснює більший вплив на медіально-латеральні коливання тіла спортсмена у фронтальній площині.

3. Існує необхідність регулярної оцінки постурального балансу спортсменів, а також розробки та широкого використання комплексу вправ, спрямованих на розвиток стійкості, з використанням методу біологічного зворотного зв'язку, з метою профрілактики травмування.

Перспективи подальших досліджень. Планується проведення досліджень по виявленню особливостей стабілометричних показників кваліфікованих спортсменів, котрі спеціалізуються в різних видах спорту, для визначення стану постурального балансу та розробки критеріїв оцінки ризику травматизму за допомогою стабілометричного методу.

8. Соловей ОМ, Соловей ДО. Теоретичні основи гандболу. Навчальний посібник [Theoretical bases of handball. Textbook]. Дніпро; 2017. 161 с.

9. Хаснутдинов НШ, Мавлиев ФА, Ахатов АМ, Назаренко АС Постуральная устойчивость спортсменов с различной спортивной специализацией и квалификацией [Postural stability in athletes with different sport specialization and qualification]. Ученые записки университета им. П.Ф. Лесгаффта. 2017: 231-4.

10. Шестаков М.П. Использование стабилометрии в спорте [Use of stabilometry in sport]. Москва: ТВТ Дивизион; 2007: 112 с.

11. Шмидт ИР. Остеохондроз позвоночника: этиология и просьилактика [Spinal cord osteohondrosis: etiology and prevention] Новосибирск: Наука; 1992: 240 с.

12. Ageberg E, Bunke S, Nilsen P, Donaldson A. [Epub ahead of print] Planning injury prevention training for youth handball players: application of the generalisable six-step intervention development process. Inj Prev. 2020; Feb 4. 1-6. doi: 10.1136/injuryprev-2019043468.

13. Aman M, Forssblad M, Larsén K. Incidence and body location of reported acute sport injuries in seven sports using a national insurance database. Scand J Med Sci Sports. 2018; 28 1147-58.

14. Bergeron MF, Mountjoy M, Armstrong N, et al. International Olympic Committee consensus statement on youth athletic development. Br J Sports Med. 2015; 49: 843-51.

15. Goes RA, Lopes LR, Cossich VRA, de Miranda VAR, Coelho ON, do Carmo Bastos R, Domenis LAM, Guimarães JAM, Grangeiro- 
Neto JA, Perini JA. Musculoskeletal injuries in athletes from five modalities: a cross-sectional study. BMC Musculoskelet Disord. 2020; 21(1):122. doi: 10.1186/s12891-020-3141-8.

16. Golomer E, Dupui P, Monod H. The effects of maturation jn self-induced dynamic body sway frequencies of girls performing acrobatics or classical dance. Eur.J.Appl.Physiol. 1997; 76 (2): 140-4.

17. Lauersen JB, Bertelsen DM, Andersen LB. The effectiveness of exercise interventions to prevent sports injuries: a systematic review and meta-analysis of randomised controlled trials. $\mathrm{Br} J$ Sports Med 2014 ;48: 871-7. doi:10.1136/bjsports-2013-092538.

18. Lisman PJ, de la Motte SJ, Gribbin TC, et al. A systematic review of the association between physical fitness and musculoskeletal injury risk: part 1- cardiorespiratory endurance. J Strength Cond Res. 2017; 31(6): 1744-57.

19. Nakagawa H, Ohashi N, Watanabe Y, Mizukoshi K. The contribution of proprioception to posture control in normal subjects. Acta Otolaryngol Suppl. 1993; 504: 112-6.

olena_kolos@ukr.net
Спортивна медицина і фізична реабілітація, № 1, 2020

20. Oshima T, Nakase J, Kitaoka K, Shima Y, Numata H, Takata $\mathrm{Y}$, Tsuchiya $\mathrm{H}$. Poor static balance is a risk factor for non-contact anterior cruciate ligament injury. Arch Orthop Trauma Surg. 2018; 138(12): 1713-8. doi: 10.1007/s00402-018-2984-z.

21. Schwesig R, Kluttig A, Leuchte S, Becker S, Schmidt H, Esperer HD. The impact of different sports on posture regulation. Sportverletz Sportschaden. 2009 Sep; 23(3): 148-54. doi: 10.1055/s-00281109576. [Article in German]

22. Wilczyński J. Postural Stability in Goalkeepers of the Polish National Junior Handball Team. J Hum Kinet. 2018 Sep 24; 63: 161-70. doi: 10.2478/hukin-2018-0016

23. Zech A, Steib S, Hentschke C, Eckhardt H, Pfeifer K. Effects of localized and general fatigue on static and dynamic postural control in male team handball athletes. J Strength Cond Res. 2012 Apr; 26(4): 1162-8. doi: 10.1519/JSC.0b013e31822dfbbb.

24. Zemková E. Sport-specific balance. Sports Med. 2014 May; 44(5): 579-90. doi: 10.1007/s40279-013-0130-1.

Надійшла 15.01.2020 